\title{
ANÁLISE COMPARATIVA DAS VANTAGENS ATRIBUÍDAS ÀS AÇÕES PREFERENCIAIS
}

\author{
Giovana Bortoluzzi Fleig ${ }^{1}$
}

\begin{abstract}
RESUMO: O presente estudo investiga as sucessivas alterações no texto do art. 17 da Lei n. ${ }^{\circ}$ 6.404/76, dispositivo que concentra as possíveis vantagens das ações preferenciais, identificando em que medida elas incrementaram a efetiva tutela do acionista investidor, estimulando a formação de poupança popular e o crescimento do setor produtivo nacional. As alterações realizadas em 2001 privilegiaram as ações preferenciais sem direito de voto, ou com direito de voto restrito, atribuindo-lhes benefícios patrimoniais. Entretanto, a redação atual deixa margem para que as companhias optem por conferir preferências pouco significativas àquelas ações.
\end{abstract}

PALAVRAS-CHAVE: Sociedade aberta, ação preferencial, preferência.

\section{Comparative analysis of the advantages attributed to preferred shares}

\begin{abstract}
The present study investigates the successive amendments in Article 17 of Brazilian law number 6.404/76, text that focuses on possible advantages of preferred shares, identifying to which extent these advantages had increased the effective custody of the investing shareholder, stimulating popular savings formation and, consequently, the growth of the national productive sector. The amendments made in 2001 privileged preferred shares without the right to vote, or with restricted right to vote, attributing patrimonial benefits. However, the current text leaves a gap so that companies opt to confer less significant preferences to those shares.

KEY-WORDS: Open capital corporation, preferred share, preference.
\end{abstract}

\footnotetext{
${ }^{1}$ Bacharel em Direito e em Desenho Industrial, Advogada. fleig@lawyer.com
} 


\section{Introdução}

O desenvolvimento do mercado de capitais brasileiro, nas últimas décadas, tem sido insuficiente para atender a necessidade de captação de recursos das empresas. Essas, muitas vezes, acabam por recorrer a financiamentos de maior custo junto ao mercado de crédito.

O fortalecimento do mercado de capitais é essencial ao crescimento da economia nacional, uma vez que viabiliza o financiamento das empresas, o crescimento da poupança interna e a democratização do capital. Para tanto, é preciso incentivar o investimentos em ações. É função do ordenamento jurídico regular o mercado de capitais, de modo a garantir liquidez, rentabilidade e segurança aos agentes econômicos, motivando-os a investir em títulos mobiliários.

Com esse intento, foram introduzidas sucessivas modificações na legislação brasileira acerca das sociedades anônimas nos últimos anos. Significativa parcela dessas reformas foi dirigida à tutela do acionista investidor, atingindo o regime jurídico das ações preferenciais. Via de regra, o perfil do investidor é de quem busca obter maiores vantagens econômicas, em detrimento de seus direitos políticos, razão pela qual as ações preferenciais lhe são especialmente atrativas.

Por tais fundamentos, a análise das ações preferenciais sintetiza as discussões acerca da proteção do acionista investidor, principal destinatário das reformas. Entretanto, é preciso verificar se tais modificações promoveram, efetivamente, a melhoria do regime das ações preferenciais. Com a edição da Lei n. $^{\circ}$ 10.303/01, houve quem ${ }^{2}$ considerasse tal modificação um retrocesso que não se coaduna com o objetivo de fomento do mercado de capitais e o prestígio às práticas de governança corporativa.

O presente estudo tem por finalidade, no que se refere às companhias de capital aberto, investigar as alterações advindas da Lei n. ${ }^{\circ}$ 10.303/01 no regime das ações preferenciais, comparando-as com aquelas introduzidas pela Lei $n .^{\circ} 9.457 / 97$, bem como com o texto original da Lei n. ${ }^{\circ}$ 6.404/76, a fim de identificar em que medida as alterações incrementaram (ou não) a efetiva tutela do acionista investidor, estimulando a formação de poupança popular e, conseqüentemente, o crescimento do setor produtivo nacional.

No primeiro capítulo apresenta-se uma breve revisão acerca dos conceitos que norteiam as ações preferenciais. Pontua-se, inclusive, aspectos do referido instituto observados no

\footnotetext{
${ }^{2}$ Sousa (2003) entende que as alterações introduzidas pela Lei n. ${ }^{\circ}$ 10.303/01, principalmente a supressão do dividendo obrigatório, consistiu em flagrante retrocesso legislativo.
} 
direito alienígena. Na segunda parte do trabalho, efetua-se a comparação das diferentes redações do art. 17 da Lei n. $^{\circ}$ 6.404/76, dispositivo que concentra as possíveis vantagens das ações preferenciais, tecendo reflexões sobre o assunto.

\section{O paradoxo da regulamentação legal}

Parcela do capital social, a ação surgiu, conforme Fazzio Júnior (2004, p. 314), a partir dos "carati, cotas de condomínio naval de companhias holandesas, no século XVI." Entretanto, Bulgarelli (1997), analisando Lehman, atribui a origem da ação ao termo holandês aktie, a partir de 1606, correspondendo à pretensão judicial ao dividendo.

A ação consiste, primeiramente, no elemento representativo do capital social da companhia. Agrega um conjunto próprio de direitos e deveres que são atribuídos ao seu titular, erigindo-o ao status de sócio. Trata-se de um valor mobiliário ${ }^{3}$ que pode ser lançado no mercado para que a sociedade se capitalize.

A ação atribui a qualidade de sócio ao seu possuidor, bem como todos os direitos essenciais inerentes, tais como os direitos de participar dos lucros ${ }^{4}$, do acervo da companhia, de fiscalizar a gestão dos negócios sociais, de preferência para a subscrição de títulos de emissão da companhia e de retirar-se da sociedade ${ }^{5}$.

As ações podem ser de várias espécies, conforme a natureza dos direitos ou vantagens que confere aos seus titulares, quais sejam: ordinárias, preferenciais ou de fruição ${ }^{6}$.

A ação preferencial outorga ao seu titular privilégios e vantagens não conferidos aos demais acionistas. Consiste em um título preferencial porque dá primazia, na ordem econômica, em relação à ação ordinária ${ }^{7}$. Concede todos os direitos da ação ordinária ${ }^{8}$,

\footnotetext{
3 Segundo Fazzio Júnior (2004, p. 315) um valor mobiliário "é um título de investimento que a sociedade anônima emite para a obtenção de recursos. É investimento social oferecido ao público, pela companhia." Devese lembrar que a ação não é o único valor mobiliário passível de ser emitido por uma sociedade anônima. Constituem exemplo de outros valores mobiliários as partes beneficiárias e as debêntures.

${ }^{4} \mathrm{O}$ direito do sócio participar nos lucros não se confunde com o direito ao dividendo. "O direito do acionista de participar dos lucros é mais amplo do que o seu direito ao dividendo, abrangendo a distribuição de reservas e a distribuição extraordinária de ações, podendo ainda adotar outras formas.

57. Constitui direito essencial do acionista (art. 109, I da Lei das Sociedades por Ações) o recebimento do dividendo, abrangendo a parcela do lucro líquido que a sociedade distribui periodicamente, observados os direitos de cada espécie e classe de ação, com base no exercício social e de acordo com a lei e os estatutos." (MORAIS; WALD, 1998, p. 48/49).

${ }^{5}$ Art. 109 da Lei n. ${ }^{\circ} 6.404 / 76$.

${ }^{6}$ Art. 15 , caput da Lei n. ${ }^{\circ} 6.404 / 76$.

${ }^{7}$ Para Retto (2004, p. 122), enquanto as ações preferenciais são privilegiadas no âmbito econômico, as ações ordinárias, ditas também ações comuns, "passaram a ser verdadeiras ações privilegiadas em relação aos direitos políticos.”
} 
podendo ser negado somente o direito ao voto, caso em que a lei ou o estatuto estabelecem benefícios de ordem econômica a fim de compensar tal supressão.

A prioridade na distribuição de dividendos, o direito a uma fração maior nos dividendos, a prioridade no reembolso do capital, quando da liquidação da sociedade, são exemplos das vantagens de ordem patrimonial que podem ser atribuídas às ações preferenciais.

A ação preferencial ainda pode conferir algum benefício de cunho político, tal como previsto no artigo 18 da Lei n. ${ }^{\circ}$ 6.404/76. O caput desse dispositivo permite ao estatuto conceder ao preferencialista o direito de eleger um ou mais membros dos órgãos da administração. Já o parágrafo único do mesmo estabelece a possibilidade do estatuto condicionar certas modificações estatutárias à aprovação dos preferencialistas.

No direito pátrio, a ação preferencial foi concebida em 1932, através do Decreto n. ${ }^{\circ}$ 21.536. A partir dessa norma, a ação ordinária deixou de ser a única espécie de ação no ordenamento jurídico brasileiro (VALVERDE, 1959). Entretanto, antes mesmo da normatização, as ações preferenciais já eram emitidas, circunstância fática inclusive reconhecida pelo Decreto n. ${ }^{\circ} 21.536$, em ser art. 14.

O indigitado decreto não restringiu o número de ações preferenciais sem direito a voto, ou com voto restrito. Tal limitação veio somente com o Decreto-lei $\mathrm{n}^{\circ}$. 2.627/40 . No texto original da Lei $n^{\circ}$. 6.404/76 o total de ações preferenciais não poderia ultrapassar dois terços da totalidade das ações emitidas ${ }^{10}$. Atualmente, com a redação dada pela Lei $n^{\circ}$. 10.303/01, o número de ações preferenciais sem direito a voto, ou com voto restrito, está restrito a $50 \%$ do total de ações emitidas ${ }^{11}$.

O artigo 111 da Lei n. ${ }^{\circ}$ 6.404/76 é a norma que autoriza ao estatuto retirar das ações preferenciais alguns direitos reconhecidos às ações ordinárias, entre eles o direito de voto. Entretanto, em seu $\S 1^{\circ}$, devolve o direito de voto às ações preferenciais na hipótese de

\footnotetext{
${ }^{8}$ Nesse sentido Carvalhosa (1994, p. 41) explica: “...não é procedente a posição doutrinária no sentido de que as ações preferenciais são títulos de renda não tendo seus titulares ingerência na empresa. Os acionistas preferenciais não participam apenas financeiramente da sociedade, mas de toda a vida social. (...) O acionista preferencial não é pois um acionista de 'segunda classe', inferior em relação aos acionistas ordinários. Ao contrário, como afirma Fran Martins, se pudessem exercer o voto juntamente com as vantagens que lhes são outorgadas, os preferencialisatas ficariam em situação de superioridade".

${ }^{9}$ O parágrafo único do art. $9^{\circ}$ do Decreto-lei $n^{\circ}$. 2.627/40 assim dispunha: "A emissão de ações preferenciais sem direito de voto não pode ultrapassar a metade do capital da companhia."

${ }^{10}$ Art. $15, \S 2^{\circ}$ da Lei n. ${ }^{\circ} 6.404 / 76$.

11 "Não se confundem as ações emitidas com as em circulação, já que a companhia pode manter parte delas em tesouraria. Também não se confundem as ações emitidas com as ações subscritas, porquanto estas representam as ações do capital que já encontraram tomadores" (RETTO, 2004, p. 129).
} 
inadimplemento dos dividendos fixos ${ }^{12}$ e dos mínimos ${ }^{13}$ por um certo período de tempo. Esse lapso, previsto no estatuto, não pode ser superior a três exercícios seguidos. Uma vez adquirido o direito de voto, esse perdurará até que sejam pagos os dividendos, até mesmo os cumulativos.

Conforme o art. 17, $\S 4^{\circ}$ da Lei n. ${ }^{\circ} 6.404 / 76$, o dividendo das ações preferenciais poderá ser cumulativo, desde que exista previsão expressa no estatuto da empresa. Desse modo, na hipótese dos dividendos não serem pagos no exercício social correspondente, acumula-se para o exercício seguinte, sucessiva e cumulativamente, até o adimplemento (BERTOLDI, 2003).

No direito comparado, observa-se que a ação preferencial geralmente atribui ao seu titular vantagens de natureza patrimonial, como preferência na distribuição dos lucros ou sobre o saldo de liquidação da sociedade. Tais preferências são instituídas por afetarem o direito ao voto do acionista, via de regra, excluindo esse direito político.

No direito inglês, as preferred shares conferem, em comparação com as ordinary shares, direitos a preferência na repartição dos lucros e/ou no reembolso do capital, no caso de liquidação.

Nos Estados Unidos, as ações preferenciais recebem, geralmente, um dividendo fixo prioritário, podendo ser outorgado também o direito de perceber fração dos lucros ou a prioridade no reembolso do capital, quando da liquidação da sociedade. Via de regra, essas ações não possuem direito de voto. Entretanto, em caso de não pagamento dos benefícios patrimoniais, o preferencialista pode adquirir esse direito, ou o direito de eleger membros do conselho de administração (RETTO, 2004).

Já na Itália, as azione di risparmio, ou ações de poupança, foram criadas no intento de atender os ensejos dos investidores, preocupados com o retorno pecuniário. Os titulares desse tipo de ação possuem uma organização muito próxima à dos possuidores de debêntures, motivo pelo qual chegaram a ser equiparados a credores da companhia.

\footnotetext{
${ }^{12}$ Dividendo fixo é aquela remuneração certa e determinado, prevista no estatuto normalmente através de um percentual incidente sobre o capital social. Depende da existência de lucro no exercício para a sua concessão. Ele não participa dos lucros remanescentes, ou seja, uma vez pago, nada mais é devido ao acionista, ainda que haja lucro excedente (REQUIÃO, 1998).

13 “Quando se tratar de dividendo prioritário mínimo, primeiramente será pago o dividendo aos preferencialistas até o montante mínimo estabelecido pelo estatuto, sendo que, caso ainda exista dividendo a ser distribuído, o mesmo será rateado entre todas as ações, inclusive entre os preferencialistas (...) enquanto a ação com dividendo fixo não participa dos lucros remanescentes, a ação com dividendo mínimo participa dos lucros distribuídos em igualdade de condições com as ordinárias, depois de assegurado a estas dividendo igual ao mínimo" (BERTOLDI, 2003, p. 278).
} 
Tais ações concedem vantagens econômicas aos seus possuidores, mas não o direito ao voto, nem mesmo de intervir nas deliberações das assembléias. Ressalta-se que não há previsão, na legislação italiana, de um mecanismo para que essas ações adquiram o direito ao voto, mesmo por inadimplemento das vantagens patrimoniais. Em razão disso, a emissão das azione di risparmio requer a cotação em bolsa das ações ordinárias, permitindo, em caso de insatisfação com a administração, que o sócio poupador possa adquirir no mercado ações ordinárias.

\section{Vantagens das ações preferenciais na legislação brasileira - Análise comparativa}

Feitas tais considerações, é preciso esclarecer que a investigação aqui desenvolvida funda-se na comparação entre as vantagens concedidas às ações preferenciais na Lei n. ${ }^{\circ}$ 6.404/76, mais especificamente em seu artigo 17, em diferentes momentos, quais sejam: no seu texto original, na redação definida pela Lei n. ${ }^{\circ}$ 9.457/97 e, mais recentemente, no texto conforme a Lei n. ${ }^{\circ} 10.303 / 01$.

\subsection{Vantagens das ações preferenciais}

Inicialmente, é preciso verificar os benefícios concedidos ao conjunto de ações preferenciais, tenham elas direito a voto ou não, especialmente aqueles consubstanciados no caput do artigo 17 da Lei n..$^{\circ}$ 6.404/76. Abaixo, apresenta-se um quadro representativo da evolução legislativa desse dispositivo:

QUADRO 1 - Vantagens das ações preferenciais no artigo 16, caput, Lei n. ${ }^{\circ}$ 6.404/76

\begin{tabular}{|l|l|l|}
\hline \multicolumn{1}{|c|}{ Texto original } & \multicolumn{1}{|c|}{$\begin{array}{c}\text { Texto conforme a Lei n. } \\
\mathbf{9 . 4 5 7 / 9 7}\end{array}$} & \multicolumn{1}{c|}{$\begin{array}{c}\text { Texto conforme a Lei n. }^{\mathbf{0}} \\
\mathbf{1 0 . 3 0 3 / 0 1}\end{array}$} \\
\hline $\begin{array}{l}\text { As preferências ou vantagens das } \\
\text { ações preferenciais podem } \\
\text { consistir: }\end{array}$ & $\begin{array}{l}\text { As preferências ou vantagens das } \\
\text { ações preferenciais: }\end{array}$ & $\begin{array}{l}\text { As preferências ou vantagens das } \\
\text { ações preferenciais podem } \\
\text { consistir: }\end{array}$ \\
\hline & $\begin{array}{l}\text { I - consistem, salvo no caso de } \\
\text { ações com direito a dividendos } \\
\text { fixos ou mínimos, cumulativos ou } \\
\text { não, no direito a dividendos no } \\
\text { mínimo dez por cento maiores do } \\
\text { que os atribuídos às ações } \\
\text { ordinárias; }\end{array}$ & \\
\hline & $\begin{array}{l}\text { II - sem prejuízo do disposto no } \\
\text { inciso anterior e no que for com } \\
\text { ele compatível, podem consistir: }\end{array}$ & \\
\hline I - em prioridade na distribuição & a) em prioridade na distribuição & I - em prioridade na distribuição \\
\hline
\end{tabular}




\begin{tabular}{|l|l|l|}
\hline de dividendos; & de dividendos; & de dividendo, fixo ou mínimo; \\
\hline $\begin{array}{l}\text { II - em prioridade no reembolso } \\
\text { do capital, com prêmio ou sem } \\
\text { ele; }\end{array}$ & $\begin{array}{l}\text { b) em prioridade no reembolso do } \\
\text { capital, com prêmio ou sem ele; }\end{array}$ & $\begin{array}{l}\text { II - em prioridade no reembolso } \\
\text { do capital, com prêmio ou sem } \\
\text { ele; ou }\end{array}$ \\
\hline $\begin{array}{l}\text { III - na acumulação das } \\
\text { vantagens acima enumeradas. }\end{array}$ & $\begin{array}{l}\text { c) na acumulação das vantagens } \\
\text { acima enumeradas. }\end{array}$ & $\begin{array}{l}\text { III - na acumulação das } \\
\text { preferências e vantagens de que } \\
\text { tratam os incisos I e II. }\end{array}$ \\
\hline
\end{tabular}

* Grifos nos textos do quadro não constantes no texto da Lei n. ${ }^{\circ}$ 6.404/76.

Como se observa, o texto original da Lei n. $^{\circ}$ 6.404/76 previa a possibilidade de se atribuir certas vantagens às ações preferenciais. A doutrina entendia que o caráter opcional, no que tange às preferências, prejudicava o potencial das ações preferenciais como capitalizadoras de fundos para a companhia. "E, com efeito, os direitos conferidos às ações preferenciais até a promulgação da Lei n. ${ }^{\circ}$ 9.457/97 consistiam em 'vantagens' formais, muitas vezes de ordem meramente cronológica" (RETTO, 2004, p. 135).

Para Morais \& Wald (1998), a classe de ações preferenciais que possuía apenas a vantagem da prioridade no reembolso do capital não se ajustavam nem dentre as quais conferiam poder político para participar da administração da empresa, nem entre aquelas que concediam significativos benefícios econômicos, a ponto de justificar a retirada do direito de voto. Na visão daqueles autores, essa situação tratava-se de uma distorção, sanada pela Lei n. ${ }^{\circ}$ $9.457 / 97$.

O texto atual suprimiu a obrigatoriedade de conceder às ações preferenciais, sem dividendos fixos ou mínimos, dividendos no mínimo $10 \%$ superiores do que aqueles conferidos às ações ordinárias. Esse benefício, que havia sido introduzido pela a Lei n. ${ }^{\circ}$ 9.457/97, era considerado pela doutrina como uma vantagem legal compulsória, sendo as demais - prioridade na distribuição de dividendos e/ou no reembolso do capital - apenas vantagens estatutárias facultativas (SOUSA, 2003).

Comparando-se os três textos normativos é imperioso concluir que a Lei n. ${ }^{\circ}$ 10.303/01 promoveu, no que tange às vantagens das ações preferenciais em geral, um retorno ao texto original da Lei n. ${ }^{\circ}$ 6.404/76. Tendo-se em conta as ações preferenciais que conservam o direito de voto, mas que possuem mera prioridade na distribuição de dividendos ou no reembolso do capital, com o retorno à redação antiga do caput do art. 17 da Lei n. ${ }^{\circ}$ 6.404/76, perderam o direito ao dividendo obrigatório majorado.

Inobstante o objeto do presente trabalho tenha sido circunscrito às companhias abertas, deve-se ponderar que tal supressão deixa sem abrigo as ações preferenciais sem direito de 
voto, ou com voto restrito, das sociedades fechadas. Isso porque o $\S 1^{\circ}$ do art. 17 da Lei n. $^{\circ}$ 6.404/76, na redação atual, exige a concessão de alguma vantagem somente às ações preferenciais de companhias abertas. Com a eliminação do dividendo majorado obrigatório, ficaram as ações preferenciais sem direito de voto, ou com voto restrito, das sociedades fechadas com os mesmos benefícios das ações preferenciais que conservam aquele direito ${ }^{14}$.

\subsection{Vantagens das ações preferenciais sem direito de voto}

Quanto à legislação das ações preferenciais sem direito a voto, pode-se dizer, de uma maneira geral, que foi desenvolvida na busca de equilibrar a ausência daquele direito através da concessão de vantagens de efetivo conteúdo econômico. A especificação dos direitos das ações sem direito a voto chega ao ápice com a nova redação do parágrafo $1^{\circ}$ do artigo 17 da Lei n. ${ }^{\circ}$ 6.404/76. Ilustra-se abaixo o quadro comparativo da evolução do texto dos parágrafos do referido dispositivo:

QUADRO 2 - Parágrafos do artigo 17 da Lei n. ${ }^{\circ}$ 6.404/76

\begin{tabular}{|c|c|}
\hline Texto anterior a Lei n. ${ }^{\circ} 10.303 / 01$ & Texto conforme a Lei n. $^{\circ} \mathbf{1 0 . 3 0 3 / 0 1}$ \\
\hline & $\begin{array}{l}\S 1^{0} \text { Independentemente do direito de receber ou } \\
\text { não o valor de reembolso do capital com prêmio ou } \\
\text { sem ele, as ações preferenciais sem direito de voto } \\
\text { ou com restrição ao exercício deste direito, somente } \\
\text { serão admitidas à negociação no mercado de valores } \\
\text { mobiliários se a elas for atribuída pelo menos uma } \\
\text { das seguintes preferências ou vantagens: } \\
\text { I - direito de participar do dividendo a ser } \\
\text { distribuído, correspondente a, pelo menos, } 25 \% \\
\text { (vinte e cinco por cento) do lucro líquido do } \\
\text { exercício, calculado na forma do art. 202, de acordo } \\
\text { com o seguinte critério: } \\
\text { a) prioridade no recebimento dos dividendos } \\
\text { mencionados neste inciso correspondente a, no } \\
\text { mínimo, } 3 \% \text { (três por cento) do valor do patrimônio } \\
\text { líquido da ação; e } \\
\text { b) direito de participar dos lucros distribuídos } \\
\text { em igualdade de condições com as ordinárias, } \\
\text { depois de a estas assegurado dividendo igual ao } \\
\text { mínimo prioritário estabelecido em conformidade } \\
\text { com a alínea } a \text {; ou } \\
\text { II - direito ao recebimento de dividendo, por }\end{array}$ \\
\hline
\end{tabular}

${ }^{14}$ BERTOLDI (2003, p. 279) não diferencia se as ações sem direito de voto, ou com voto restrito, são de companhias abertas ou fechadas, mas se as ações estão ou não admitidas à negociação no mercado de valores mobiliários. "Assim, teremos as seguintes hipóteses: a) patamares mínimos de vantagens atribuíveis às ações preferenciais não negociadas no mercado de valores mobiliários e b) patamares mínimos de vantagens atribuíveis às ações preferenciais negociadas no mercado de valores mobiliários. As vantagens mínimas atribuíveis às ações preferenciais não negociadas no mercado de valores mobiliários estão descritas nos incisos I, II, e III do art. 17 da Lei 6.404/76". 


\begin{tabular}{|c|c|}
\hline & $\begin{array}{l}\text { ação preferencial, pelo menos } 10 \% \text { (dez por cento) } \\
\text { maior do que o atribuído a cada ação ordinária; } \\
\text { III - direito de serem incluídas na oferta pública } \\
\text { de alienação de controle, nas condições previstas no } \\
\text { art. 254-A, assegurado o dividendo pelo menos } \\
\text { igual ao das ações ordinárias. }\end{array}$ \\
\hline & $\begin{array}{l}\S 2^{0} \text { Deverão constar do estatuto, com precisão e } \\
\text { minúcia, outras preferências ou vantagens que } \\
\text { sejam atribuídas aos acionistas sem direito a voto, } \\
\text { ou com voto restrito, além das previstas neste } \\
\text { artigo. }\end{array}$ \\
\hline $\begin{array}{l}\S 1^{\circ} \text { Os dividendos, ainda que fixos ou } \\
\text { cumulativos, não poderão ser distribuídos em } \\
\text { prejuízo do capital social, salvo quando, em caso de } \\
\text { liquidação da companhia, essa vantagem tiver sido } \\
\text { expressamente assegurada. }\end{array}$ & $\begin{array}{l}\text { § } 3^{\circ} \text { Os dividendos, ainda que fixos ou cumulativos, } \\
\text { não poderão ser distribuídos em prejuízo do capital } \\
\text { social, salvo quando, em caso de liquidação da } \\
\text { companhia, essa vantagem tiver sido expressamente } \\
\text { assegurada. }\end{array}$ \\
\hline $\begin{array}{l}\S 2^{\circ} \text { Salvo disposição em contrário do estatuto, o } \\
\text { dividendo prioritário não é cumulativo, a ação com } \\
\text { dividendo fixo não participa dos lucros } \\
\text { remanescentes e a ação com dividendo mínimo } \\
\text { participa dos lucros distribuídos em igualdade de } \\
\text { condições com as ordinárias, depois de a estas } \\
\text { assegurado dividendo igual ao mínimo. }\end{array}$ & $\begin{array}{l}\text { § } 4^{0} \text { Salvo disposição em contrário no estatuto, o } \\
\text { dividendo prioritário não é cumulativo, a ação com } \\
\text { dividendo fixo não participa dos lucros } \\
\text { remanescentes e a ação com dividendo mínimo } \\
\text { participa dos lucros distribuídos em igualdade de } \\
\text { condições com as ordinárias, depois de a estas } \\
\text { assegurado dividendo igual ao mínimo. }\end{array}$ \\
\hline $\begin{array}{l}\S 3^{\circ} \text { O dividendo fixo ou mínimo e o prêmio de } \\
\text { reembolso estipulados em determinada importância } \\
\text { em moeda, ficarão sujeitos à correção monetária } \\
\text { anual, por ocasião da assembléia-geral ordinária, } \\
\text { aos mesmos coeficientes adotados na correção do } \\
\text { capital social, desprezadas as frações de centavo. }\end{array}$ & \\
\hline $\begin{array}{l}\text { § } 4^{\circ} \text { O estatuto não pode excluir ou restringir o } \\
\text { direito das ações preferenciais de participar dos } \\
\text { aumentos de capital decorrentes de correção } \\
\text { monetária (artigo 167) e de capitalização de } \\
\text { reservas e lucros (artigo 169). }\end{array}$ & $\begin{array}{l}\text { § } 5^{0} \text { Salvo no caso de ações com dividendo fixo, o } \\
\text { estatuto não pode excluir ou restringir o direito das } \\
\text { ações preferenciais de participar dos aumentos de } \\
\text { capital decorrentes da capitalização de reservas ou } \\
\text { lucros (art. 169). }\end{array}$ \\
\hline $\begin{array}{l}\S 5^{\circ} \mathrm{O} \text { estatuto pode conferir às ações preferenciais, } \\
\text { com prioridade na distribuição de dividendo } \\
\text { cumulativo, o direito de recebê-lo, no exercício em } \\
\text { que o lucro for insuficiente, à conta das reservas de } \\
\text { capital de que trata o } \S 1^{\circ} \text { do artigo } 182 \text {. } \\
\end{array}$ & $\begin{array}{l}\S 6^{0} \mathrm{O} \text { estatuto pode conferir às ações preferenciais } \\
\text { com prioridade na distribuiçâo de dividendo } \\
\text { cumulativo, o direito de recebê-lo, no exercício em } \\
\text { que o lucro for insuficiente, à conta das reservas de } \\
\text { capital de que trata o } \S 1^{\circ} \text { do art. } 182 \text {. } \\
\end{array}$ \\
\hline \multirow[t]{2}{*}{$\begin{array}{l}\S 6^{\circ} \text { O pagamento de dividendo fixo ou mínimo às } \\
\text { ações preferenciais não pode resultar em que, da } \\
\text { incorporação do lucro remanescente ao capital } \\
\text { social da companhia, a participação do acionista } \\
\text { residente ou domiciliado no exterior nesse capital, } \\
\text { registrada no Banco Central do Brasil, aumente em } \\
\text { proporção maior do que a do acionista residente ou } \\
\text { domiciliado no Brasil. }\end{array}$} & \\
\hline & $\begin{array}{l}\S 7^{0} \text { Nas companhias objeto de desestatização } \\
\text { poderá ser criada ação preferencial de classe } \\
\text { especial, de propriedade exclusiva do ente } \\
\text { desestatizante, à qual o estatuto social poderá } \\
\text { conferir os poderes que especificar, inclusive o } \\
\text { poder de veto às deliberações da assembléia-geral } \\
\text { nas matérias que especificar. }\end{array}$ \\
\hline
\end{tabular}


De início, observa-se que, na nova redação dos parágrafos do artigo 17 da Lei n. ${ }^{\circ}$ 6.404/76, não há correspondentes para os antigos parágrafos $3^{\circ}$ e $6^{\circ}$. A Lei n. ${ }^{\circ} 10.303 / 01$ introduziu o parágrafo $7^{\circ}$ e modificou essencial e profundamente o regime das ações preferenciais sem direito de voto, ou com restrição ao exercício deste direito, nos parágrafos $1^{\circ}$ e $2^{\circ}$. É essa última modificação que interessa ao presente trabalho.

Carvalhosa (1994), anteriormente à Lei n. ${ }^{\circ}$ 9.457/97, já entendia que a retirada ou restrição no direito de voto do acionista requer a concessão de efetivos benefícios econômicos às ações preferenciais. Pugnava que as ações sem esse direito deveriam possuir dividendo majorado, inclusive quando previstos dividendos fixos ou mínimos.

Observa-se que, embora o $\S 1^{\circ}$ do art. 17, na redação atual, elenque uma série de vantagens, e determine a obrigatoriedade de conceder ao menos uma às ações preferenciais sem direito de voto ou com voto restrito, tal norma tem um destinatário específico: as companhias abertas que pretendam negociar esses títulos no mercado de valores mobiliários.

Sobre tal dispositivo pode-se afirmar que institui vantagens compulsórias, pois exige que o preferencialista goze de pelo menos uma das três vantagens listadas nos incisos do $\S 1^{\circ}$.

A primeira vantagem do inciso I do $\S 1^{\circ}$ do art. 17 , conforme o texto dado pela Lei $n .^{\circ}$ 10.303/01, constitui-se no em um dividendo mínimo de pelo menos 3\% do patrimônio líquido da ação, desde que o dividendo obrigatório da companhia seja pelo menos $25 \%$ do lucro líquido ajustado. Para tanto, divide-se o patrimônio líquido da sociedade pelo número de ações, chegando-se ao patrimônio líquido por ação. O dividendo do preferencialista será então no mínimo 3\% desse valor. Depois pago às ordinárias dividendo igual ao mínimo prioritário, o lucro remanescente deve ser distribuído eqüitativamente entre ações preferenciais e ordinárias (TOZZINI; BERGER, 2002).

Note-se que a segunda preferência ${ }^{15}$ retorna ao texto do art. 17, caput, I com a redação da Lei n. ${ }^{\circ}$ 9.457/97, que constituía uma vantagem legal compulsória a todas as ações preferenciais, fossem de companhias abertas ou fechadas, com ou sem direito de voto. $\mathrm{Na}$ redação positiva, o indigitado benefício constitui uma das opções que a lei dá às companhias abertas para contrabalançar a restrição total ou parcial no direito de voto das ações preferenciais $^{16}$.

\footnotetext{
${ }^{15}$ Refere-se ao art. $17, \S 1^{\text {o }}$, II da Lei n. ${ }^{\circ} 6.404 / 76$.

16 Sobre o dividendo diferenciado advoga Sousa (2003) que “...lamentavelmente, o legislador deixou de considerá-lo como vantagem legal compulsória, transformando-o em vantagem estatutária facultativa, pois pode o estatuto social conferir apenas a (s) vantagem (ns) do inciso I e/ou inciso III, silenciando quanto ao dividendo
} 
O direito de ter as ações preferenciais incluídas na oferta pública de alienação de controle, conforme o art. 254-A da Lei n. ${ }^{\circ}$ 6.404/76, assegurado dividendo ao menos igual ao das ações ordinárias, é o benefício do inciso III do $\S 1^{\circ}$ do art. 17. Assim, as ações preferenciais poderão ser vendidas nas mesmas condições das ordinárias, na hipótese de mudança do controle acionário da sociedade, operação conhecida também como tag along.

Considerando-se que: a) o referido art. 254-A garante a oferta pública para aquisição de ações, quando da alienação do controle da sociedade aberta, aos titulares de ações votantes; b) a ação ordinária possui direito de voto; conclui-se que os titulares das ações preferenciais com o benefício do inciso III do $\S 1^{\circ}$ do art. 17 da Lei n. ${ }^{\circ}$ 6.404/76 "serão equiparados aos titulares de ações ordinárias (mesmos direitos na alienação do controle e na percepção de dividendos), não havendo vantagem patrimonial efetiva" (RETTO, 2004, p. 139).

Dentre estas três preferências compulsórias, não há dúvida de que a única que pode ser considerada como real vantagem é a prevista no inciso II, que trata do denominado dividendo diferenciado, pois as previstas nos incisos I (participação no dividendo líquido) e III ('tag along' ou direito de saída conjunta) não são vantagens efetivas, eis que a primeira só será vantajosa se o patrimônio líquido da sociedade for bastante elevado, enquanto que a segunda, que trata do direito de saída conjunta ou "tag along", só será usufruída pelo acionista preferencial se ocorrer a alienação do controle da companhia aberta, o que é uma eventualidade. (SOUSA, 2003).

Comparando-se as três possíveis vantagens, é de se concluir que a que melhor compensa a supressão, total ou parcial, do direito de voto, é a do inciso II.

\section{Considerações Finais}

A adequada regulamentação das ações preferenciais é essencial para efetivar a democratização do capital e gerar condições para capitalização das companhias. Para tanto, deve a lei garantir efetiva vantagem econômica às ações preferenciais, de modo a compensar a restrição às prerrogativas políticas do sócio.

Considerando-se as vantagens possíveis a qualquer ação preferencial, com ou sem direito a voto, consubstanciadas no caput do artigo 17 da Lei n. ${ }^{\circ}$ 6.404/76, pode-se afirmar que as alterações mais recentes promoveram um retorno ao texto original da Lei n. ${ }^{\circ}$ 6.404/76. Com

diferenciado, o que demonstra que o acionista preferencial pode não ter o direito de voto ou tê-lo com restrição e não gozar de uma vantagem real." 
isso, deixou de existir o direito ao dividendo obrigatório majorado, fato que, em certos casos, piorou a situação do preferencialista.

Considerando-se as ações preferenciais que conservam o direito de voto, mas que possuem mera prioridade na distribuição de dividendos ou no reembolso do capital, pode-se dizer que a mudança foi prejudicial, pois perderam o direito ao dividendo obrigatório $10 \%$ maior do que o conferido às ações ordinárias.

É nítido que a Lei n. ${ }^{\circ}$ 10.303/01 buscou atribuir maiores preferências para aquelas ações sem direito de voto ou com voto restrito das sociedades abertas. Não se preocupou o legislador de 2001 com as ações preferenciais sem direito de voto, ou com voto restrito, das sociedades fechadas. Com a eliminação do dividendo majorado obrigatório, e a referência específica do art. $17, \S 1^{\circ}$ da Lei n. $.^{\circ} 6.404 / 76$ às companhias abertas, àquelas restaram somente os benefícios do caput do art. 17, insuficientes para compensar a perda ou restrição do direito de voto.

Compartilha-se aqui a ponderação feita por Retto (2004), de que atribuição da vantagem do art. $17, \S 1^{\circ}$, III da Lei n. $6.404 / 76$ não constitui, por si só, um benefício econômico efetivo, capaz de compensar a ausência ou restrição do direito de voto de uma ação preferencial.

Por essas razões, conclui-se que as alterações procedidas pela Lei n. ${ }^{\circ}$ 10.303/01 privilegiaram a tutela do preferencialista sem direito de voto, ou com direito de voto restrito, em detrimento das garantias antes atribuídas a qualquer titular de ação preferencial. Entende-se que o esforço tem sido direcionado para somente compensar a supressão, total ou parcial, do direito de voto do acionista investidor através de benefícios patrimoniais. Entretanto, tal iniciativa pode não ser suficiente, uma vez que deixa margem para as companhias optarem por conferir preferências pouco significativas àquelas ações.

\section{Referências Bibliográficas}

AGUIAR, Danilo Augusto Barboza de. Proteção dos acionistas minoritários das sociedades anônimas abertas como forma de promover o desenvolvimento do mercado de capitais nacional: alterações no regime legal das ações preferenciais. Revista de Direito Bancário, do Mercado de Capitais e da Arbitragem, São Paulo, ano 6, n. 22, p. 88-127, out.-dez. 2003.

BERTOLDI, Marcelo M. Curso avançado de direito comercial: teoria geral do direito comercial, direito societário. V. I. 2. ed. São Paulo: Revista dos Tribunais, 2003. 
BRASIL. Lei n. ${ }^{\circ}$ 6.404, de 15 de dezembro de 1976. Dispõe sobre a sociedade por ações. In: EDITORA SARAIVA. Código Comercial. 45. ed. São Paulo, 2000. p. 467-590. In: EDITORA REVISTA DOS TRIBUNAIS. Constituição Federal, Código

Comercial, Código Tributário Nacional. 7. ed. São Paulo, 2005. p. 659-753.

. Lei n. ${ }^{\circ}$ 9.457, de 05 de maio de 1997. Altera dispositivos da Lei n. ${ }^{\circ} 6.404$, de 15 de dezembro de 1976, que dispõe sobre a sociedade por ações e da Lei n. ${ }^{\circ} 6.385$, de 7 de dezembro de 1976, que dispõe sobre o mercado de valores mobiliários e cria a Comissão de Valores Mobiliários. In: EDITORA SARAIVA. Código Comercial. 45. ed. São Paulo, 2000. p. 1027.

Lei n. ${ }^{\circ}$ 10.303, de 31 de outubro de 2001. Altera e acrescenta dispositivos na Lei 6.404, de 15 de dezembro de 1976, que dispõe sobre a sociedade por ações, e na Lei 6.385, de 7 de dezembro de 1976, que dispõe sobre o mercado de valores mobiliários e cria a Comissão de Valores Mobiliários. In: EDITORA REVISTA DOS TRIBUNAIS. Constituição Federal, Código Comercial, Código Tributário Nacional. 7. ed. São Paulo, 2005. p. 1127-1129.

BULGARELLI, Waldirio. Manual das Sociedades Anônimas. 9. ed. São Paulo: Atlas, 1997.

CARVALHOSA, Modesto. Ações preferenciais desprovidas de preferências. Revista dos Tribunais, São Paulo, ano 83, v. 707, p. 39-44, set. 1994.

COELHO, Fábio Ulhoa. Manual de direito comercial. 15. ed. São Paulo: Saraiva, 2004.

FAZZIO JÚNIOR, Waldo. Manual de direito comercial. 4. ed. São Paulo: Atlas, 2004.

MORAIS, Luiza Rangel de; WALD, Arnoldo. Regime das ações preferenciais na nova legislação societária. Revista de Direito Bancário e do Mercado de Capitais, São Paulo, ano 1, n. 1, p. 41-57, jan.-abr. 1998.

REQUIÃO, Rubens. Curso de direito comercial. v. II. 23. ed. São Paulo: Saraiva, 1998.

RETTO, Marcel Gomes Bragança. Evolução legislativa das ações preferenciais no Brasil e os institutos a ela relacionados. Revista de Direito Mercantil, Industrial, Econômico e Financeiro, São Paulo, v. 43, n. 133, p. 121-142, jan.-mar. 2004.

SOUSA, Cláudio Calo. Dividendo diferenciado na nova Lei da S.A. (Lei $n^{\circ}$ 10.303/2001): flagrante retrocesso. Jus Navegandi, Teresina, ano 7, n. 65, mai. 2003. Disponível em: <http://jus2.uol.com.br/doutrina/texto.asp?id=4044>. Acesso em: 07 ago. 2005.

TOZZINI, Syllas; BERGER, Renato. Dividendos das ações preferenciais e aquisição de direito de voto pelos preferencialistas . Jus Navigandi, Teresina, a. 6, n. 57, jul. 2002. Disponível em: $<$ http://jus2.uol.com.br/doutrina/texto. asp?id=2968>. Acesso em: 02 out. 2005.

VALVERDE, Trajano Miranda. Sociedades por ações: comentários ao Decreto-lei n. 2.627, de 26 de setembro de 1940. 3. ed. Rio de Janeiro: Forense 1959. 